\title{
PENINGKATAN MOTIVASI DAN HASIL BELAJAR BIOLOGI \\ MATERI SISTEM TRANSPORTASI MELALUI MODEL \\ STAD (STUDENT TEAM ACHIEVEMENT DIVISIONS) \\ BAGI SISWA XI IPA 1 SEMESTER GANJIL \\ DI SMA NEGERI 1 KARANGRAYUNG \\ TAHUN 2015/2016
}

\author{
Tugiyati*) \\ SMAN 1 Karangrayung
}

\begin{abstract}
Abstrak
Rumusan masalah pada penelitian ini adalah apakah melalui model pembelajaran STAD (Student Team Achievement Divisions) mampu meningkatkan motivasi dan hasil belajar biologi konsep sistem transportasi bagi siswa kelas XI IPA 1 SMA Negeri 1 Karangrayung. PTK ini ditempuh dalam 2 siklus. Terjadi perubahan motivasi dan hasil belajar siswa, motivasi belajar yang baik dan sangat baik meningkat sebesar $70 \%$ dari kondisi awal hanya $20 \%$ menjadi $90 \%$ pada akhir siklus II. Hasil belajar siswa yang tuntas juga mengalami peningkatan dari kondisi awal hanya $30 \%$ menjadi $92,5 \%$
\end{abstract}

Kata Kunci: Motivasi, Hasil belajar, STAD 


\section{PENDAHULUAN}

Berbagai upaya telah dilakukan dalam mewujudkan peningkatan kualitas pendidikan. Seperti merevisi hingga merubah kurikulum ,menyelenggarakan pelatihan-pelatihan sumber daya manusia dalam pelaksanaan kurikulum serta menyelenggarakan dan meningkatkan pola kegiatan belajar yang disesuaikan dengan perkembangan IPTEK dan perkembangan masyarakat Indonesia. Sumber daya manusia Indonesia tergolong sangat rendah. Sumber daya manusia sangat ditentukan oleh kualitas pendidikan. Dengan kata lain jika kualitas pendidikan suatu Negara rendah maka kualitas sumber daya manusianya juga rendah.

Pada mata pelajaran Biologi banyak siswa yang mengalami kesulitan belajar. Berdasarkan hasil ulangan harian yang pertama dari 38 (tiga puluh delapan) siswa hanya 25 (duapuluh lima) siswa yang tuntas belajar atau hanya $65,7 \%$ siswa yang tuntas belajar.

Berdasarkan pengamatan di kelas XI IPA 1 di SMA Negeri 1 Karangrayung Kabupaten Grobogan, banyak permasalahan yang dialami siswa maupun guru,antara lain : siswa kurang bersemangat dalam belajar, Guru mengalami kesulitan dalam mengajarkan materi ini, dan kurangnya buku referensi siswa yang menghambat penguasaan pembelajaran .

Pada pembelajaran konsep sistem transportasi agar proses belajar berlangsung menyenangkan, dapat mempermudah siswa dalam memahami isi pelajaran, peneliti menggunakan model STAD (Student Team Achievement Divisions. Dalam penerapan model pembelajaran ini selain dengan tanya jawab, guru juga memberi kesempatan kepada siswa untuk menunjukkan keberanian, keterlibatan serta pemahaman dalam proses pembelajaran.

Rumusan masalah dalam penelitian ini adalah: 1).bagaimanakah model STAD (Student Team Achievement Divisions) mampu meningkatkan motivasi siswa kelas XI IPA 1 SMA Negeri 1 Karangrayung, 2). apakah model pembelajaran STAD (Student Team Achievement Divisions) mampu meningkatkan hasil belajar siswa kelas XI IPA 1 SMA Negeri 1 Karangrayung Kabupaten Grobogan semester ganjil tahun pelajaran 2015/2016?

Tujuan penelitian yang hendak dicapai dalam penelitian ini adalah :1). mengidentifikasi peningkatan motivasi belajar siswa melalui model pembelajaran STAD (Student Team Achievement Divisions), 2). mendeskripsikan peningkatan 
hasil belajar biologi konsep sistem transportasi melalui model pembelajaran STAD (Student Team Achievement Divisions) bagi siswa kelas XI IPA 1 SMA Negeri 1 Karangrayung Kabupaten Grobogan Semester ganjil tahun pelajaran 2015/2016?

Penelitian ini diharapkan dapat bermanfaat untuk meningkatkan motivasi dan hasil belajar siswa dalam pembelajaran biologi, dapat mengembangkan kualitas guru, meningkatkan kualitas dan menumbuhkan iklim pembelajaran yang aktif serta menyenangkan di sekolah.

\section{METODE PENELITIAN}

Penelitian ini dilaksanakan selama kurang lebih 6 bulan atau 24 minggu, yaitu antara bulan Juli sampai dengan Desember 2015 di kelas XI IPA 1 SMA Negeri 1 Karangrayung yang beralamat di Jl. Karangrayung-Juwangi Km.1, Karangrayung kabupaten Grobogan.

Penelitian tindakan kelas ini dilaksanakan untuk siswa kelas XI IPA1 tahun 2015/2016 yang berjumlah 33 orang yang terdiri dari 9 laki-laki dan 24 perempuan. Sumber data yang digunakan data persentase motivasi siswa dalam proses pembelajaran dan data hasil ulangan harian (tes tertulis).

Teknik pengambilan data berupa tes dan non-tes. Teknik tes digunakan untuk mendapatkan skor kemampuan akademik siswa pada materi Sistem Transportasi pada siklus 1 dan 2. Teknik non tes dengan menggunakan lembar pengamatan dan check list untuk mendapatkan data tentang motivasi siswa dalam pembelajaran biologi materi sistem transportasi selama pelaksanaan siklus penelitian.

Indikator kinerja penelitian ini yaitu penelitian dikatakan berhasil apabila 85\% siswa telah mencapai nilai minimal 71 dari kriteria persentase motivasi siswa dan minimal 78 dari kriteria nilai hasil belajar materi sisem transportasi.

Penelitian ini terbagi dalam 2 siklus, dimana siklus 1 materi Sistem Transportasi pada indikator menjelaskan fungsi darah, jantung, dan pembuluh darah (arteri dan vena) sedangkan siklus 2 menjelaskan dasar-dasar transfusi darah. Adapun prosedur penelitian sebagai berikut: Perencanaan, Implementasi tindakan, Guru mengkondisikan siswa di dalam kelas dan menjelaskan tentang model STAD serta kegiatan-kegiatan yang akan dilakukan selama pembelajaran berlangsung, Tahap observasi dan evaluasi, dan Refleksi. 


\section{HASIL PENELITIAN DAN PEMBAHASAN}

\section{Hasil Penelitian}

\section{Pra Siklus}

Data motivasi belajar siswa kelas XI IPA 1 sebelum dilakukan penelitian (pra siklus) dapat dilihat pada tabel berikut ini :

Tabel 1 Distribusi Frekuensi Motivasi Belajar Siswa Pra Siklus Kelas XI IPA SMA Negeri 1 Karangrayung

\begin{tabular}{|l|c|c|c|}
\hline Kategori & Nilai & Frekuensi & Persentase \\
\hline Sangat Baik & $91-100$ & 1 & $3,0 \%$ \\
\hline Baik & $81-90$ & 6 & $18,2 \%$ \\
\hline Cukup & $71-80$ & 15 & $45,5 \%$ \\
\hline Kurang & $0-70$ & 11 & $33,3 \%$ \\
\hline Jumlah & & 33 & $100 \%$ \\
\hline
\end{tabular}

Hasil dari check list motivasi belajar siswa dalam mengikuti pembelajaran sistem transportasi sebagaimana tabel 3 di atas menunjukkan bahwa hanya ada $66,7 \%$ dari jumlah siswa kelas XI IPA 1 yang mempunyai motivasi memadai untuk belajar yang terdiri dari 45,5\% mempunyai motivasi cukup; 18,2\% siswa bermotivasi baik, dan 3,0\% bermotivasi sangat baik. 33,3\% siswa masih belum termotivasi untuk belajar.

Data hasil belajar siswa yang diperoleh dari hasil ulangan harian bisa dilihat pada tabel berikut ini:

Tabel 2 Distribusi Nilai Hasil Belajar Siswa Pra Siklus Kelas XI IPA ${ }_{1}$ SMA Negeri 1 Karangrayung

\begin{tabular}{|l|c|c|c|}
\hline Kategori & Nilai & Frekuensi & Persentase \\
\hline Sangat Baik & $91-100$ & 1 & $3,0 \%$ \\
\hline Baik & $81-90$ & 10 & $30,3 \%$ \\
\hline Cukup & $78-80$ & 11 & $33,3 \%$ \\
\hline Kurang & $0-78$ & 11 & $33,3 \%$ \\
\hline Jumlah & & 33 & $100 \%$ \\
\hline
\end{tabular}


Hasil belajar siswa pada materi sistem transportasi terlihat, bahwa baru $66,6 \%$ dari jumlah siswa di kelas $\mathrm{XI} \mathrm{IPA}_{1}$ yang telah tuntas belajar. Persentase sebesar itu tersebar pada 3 kategori yaitu cukup, baik, dan sangat baik. Untuk kategori cukup sebesar 33,3\%, baik sebesar 30,3\%, dan sangat baik sebesar 3,0\%. 33,3\% dari jumlah siswa seluruhnya masih kurang nilainya.

\section{Siklus 1}

Kegiatan pembelajaran pada siklus 1 dilaksanakan pada hari Senin tanggal 7 September 2015 dan Jum'at tanggal 11 September 2015 dilakukan dengan menggunakan model pembelajaran STAD (Student Team Achievement Divisions).

Aktivitas para siswa dalam pembelajaran sistem transportasi pada indikator menjelaskan fungsi darah, jantung, dan pembuluh darah dengan model STAD bisa terlihat dari gambar-gambar di bawah ini:

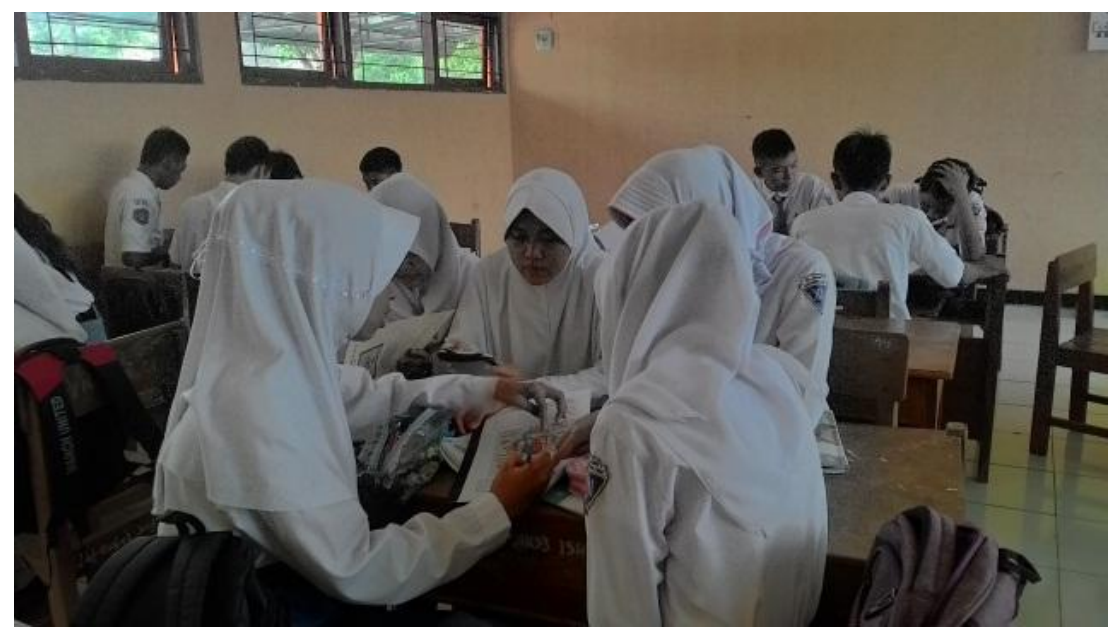

Gambar 1 Diskusi Kelompok Siklus 1

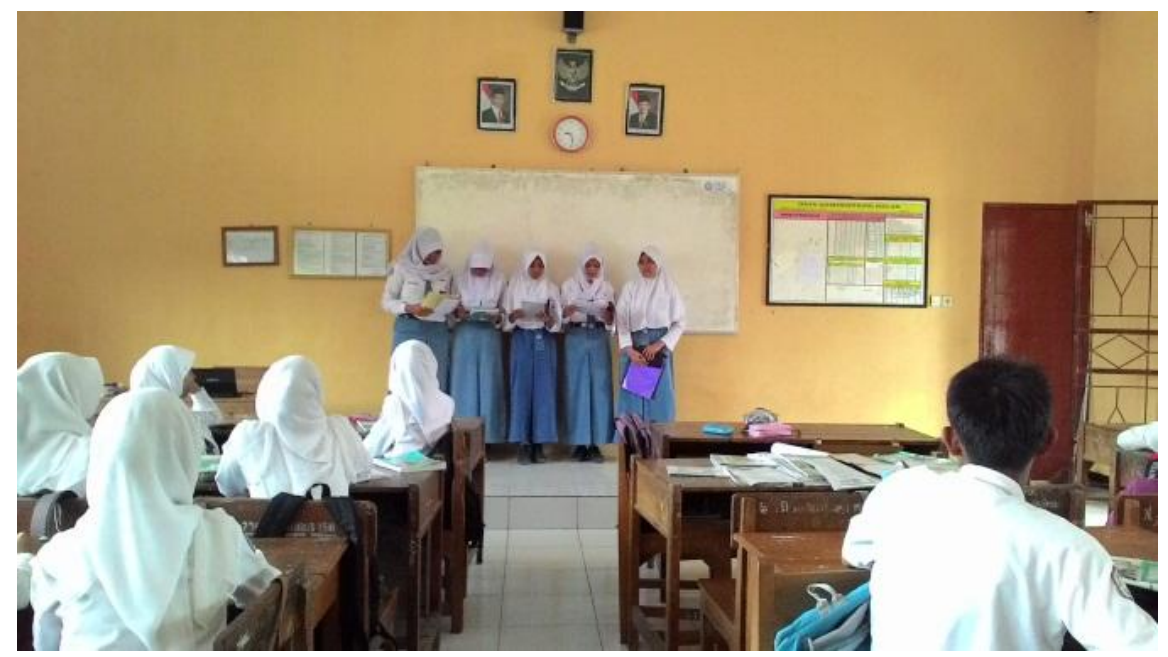

Gambar. 2 Presentasi Kelompok I Pada Siklus 1 


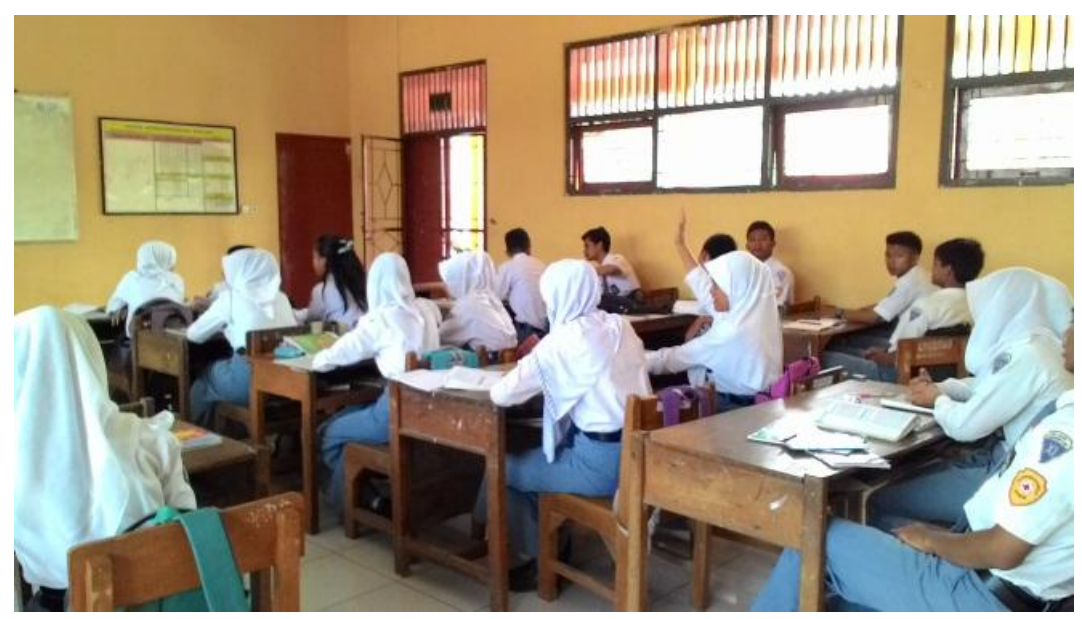

Gambar. 3 Sesi Tanya Jawab Siklus 1

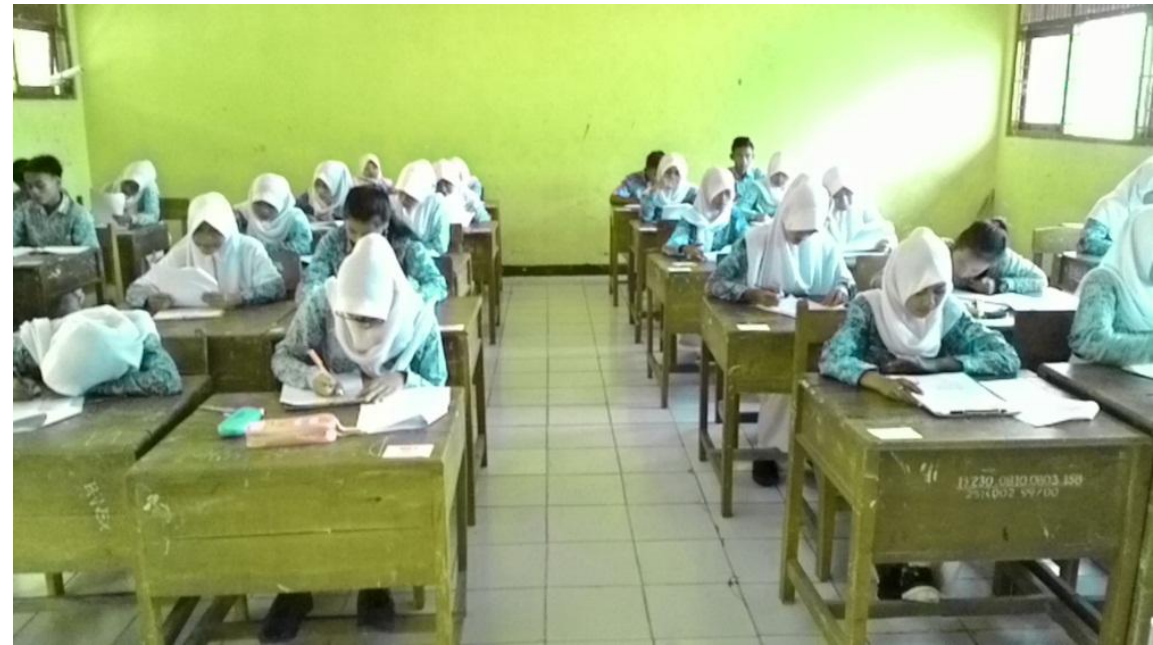

Gambar. 4 Evaluasi Siklus 1

Keaktifan para siswa sebagai perwujudan dari motivasi belajar mereka dapat dilihat dari gambar-gambar di atas, dimana para siswa berperan aktif dalam pembelajaran. Nampak dari gambar ada yang mengacungkan tangan untuk bertanya, ini menunjukkan adanya peningkatan motivasi belajar siswa.

Berdasarkan data check list motivasi pada kegiatan belajar mengajar siklus 1, diperoleh data sebagai berikut: 
Tabel 3 Distribusi Frekuensi Motivasi Belajar Siswa Siklus 1 Kelas XI IPA SMA Negeri 1 Karangrayung

\begin{tabular}{|l|c|c|c|}
\hline Kategori & Nilai & Frekuensi & Persentase \\
\hline Sangat Baik & $91-100$ & 1 & $3,0 \%$ \\
\hline Baik & $81-90$ & 11 & $33,3 \%$ \\
\hline Cukup & $71-80$ & 15 & $45,5 \%$ \\
\hline Kurang & $0-70$ & 6 & $18,2 \%$ \\
\hline Jumlah & & 33 & $100 \%$ \\
\hline
\end{tabular}

Hasil dari check list motivasi belajar siswa dalam mengikuti pembelajaran sistem transportasi sebagaimana tabel 5 di atas menunjukkan bahwa ada 18,2\% siswa mempunyai motivasi kurang, sedangkan yang termotivasi ada $81,8 \%$ dari jumlah siswa kelas XI IPA 1 yang terdiri dari 45,5\% motivasi cukup; 33,3\% motivasi baik, dan yang sangat termotivasi ada $3 \%$.

Persentase motivasi belajar siswa yang meningkat akan menyebabkan hasil belajar siswa kelas XI IPA 1 pada siklus 1 juga mengalami peningkatan seperti pada data hasil evaluasi belajar siswa pada tabel berikut ini:

Tabel 4 Distribusi Nilai Hasil Belajar Siswa Siklus 1 Kelas XI IPA 1 SMA Negeri 1 Karangrayung

\begin{tabular}{|l|c|c|c|}
\hline Kategori & Nilai & Frekuensi & Persentase \\
\hline Sangat Baik & $91-100$ & 3 & $9,1 \%$ \\
\hline Baik & $81-90$ & 17 & $51,5 \%$ \\
\hline Cukup & $78-80$ & 7 & $21,2 \%$ \\
\hline Kurang & $0-78$ & 6 & $18,2 \%$ \\
\hline Jumlah & & 33 & $100 \%$ \\
\hline
\end{tabular}

Hasil belajar siswa pada materi sistem transportasi terlihat, bahwa baru $81,8 \%$ dari jumlah siswa di kelas $\mathrm{XI}_{\mathrm{IPA}}$ yang telah tuntas belajar. Berdasarkan temuan di atas dievaluasi langkah-langkah yang telah direncanakan dan dilaksanakan pada siklus 1 karena belum mampu mencapai tujuan yang diharapkan oleh peneliti, yaitu sebesar $85 \%$ maka peneliti mengadakan revisi- 
revisi mengenai langkah-langkah yang ditempuh dalam penelitian, peneliti melanjutkan pada program siklus 2 yang direncanakan dengan berbagai revisi yaitu peneliti memantau jalannya pembelajaran dengan model STAD.

\section{Siklus 2}

Siklus 2 dilaksanakan pada tanggal 21 dan 25 September 2015 di kelas XI IPA $_{1}$ SMA Negeri 1 Karangrayung. Aktivitas para siswa dalam pembelajaran sistem transportasi pada indikator menjelaskan dasar-dasar transfusi darah dengan model STAD dapat dilihat dari gambar-gambar berikut ini:

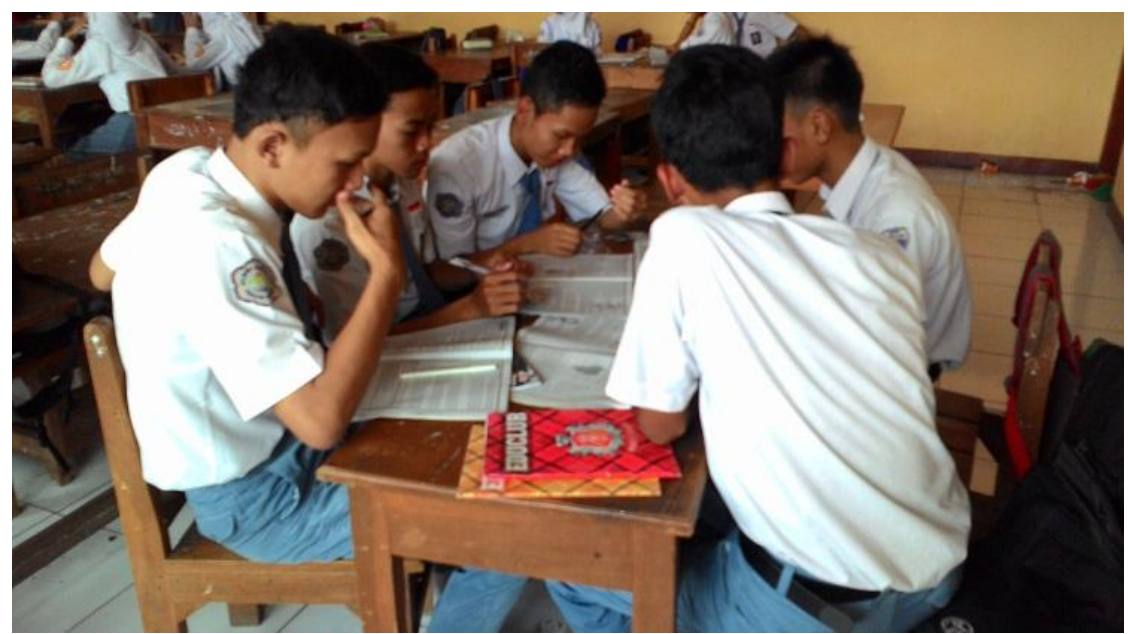

Gambar. 5 Diskusi Kelompok Siklus 2

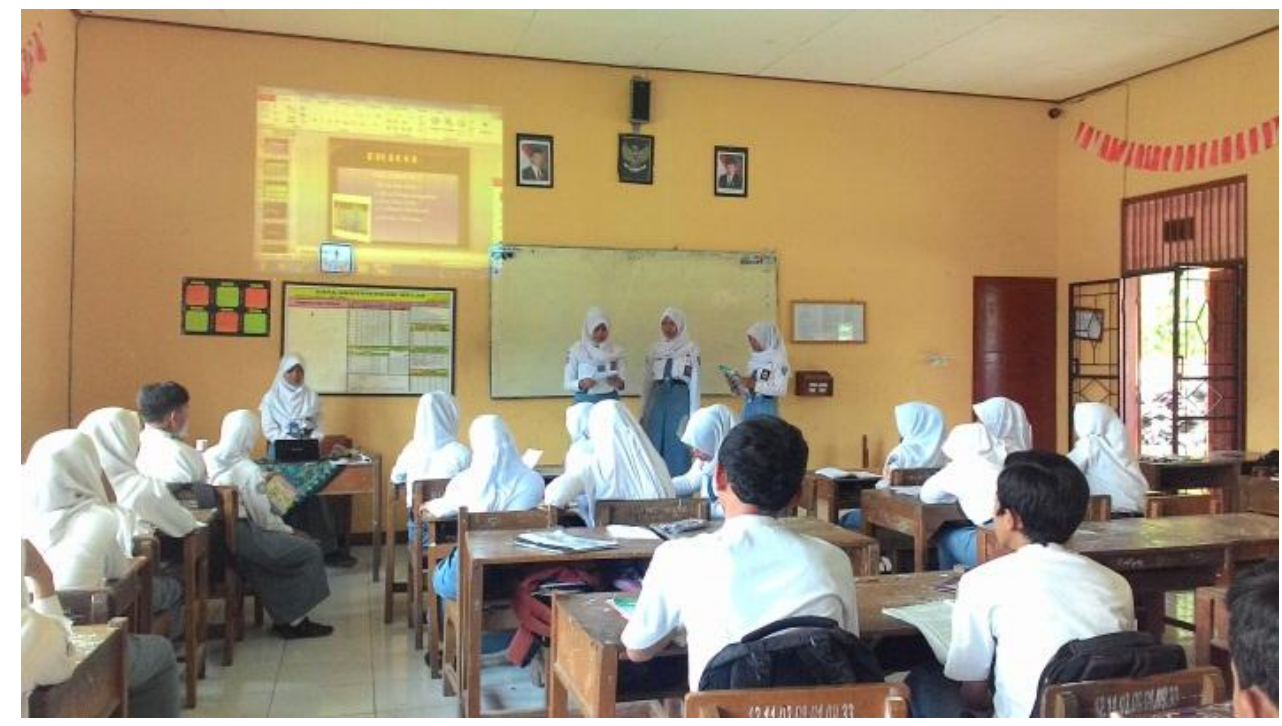

Gambar. 6 Presentasi Kelompok II Siklus 2 (dengan power point) 


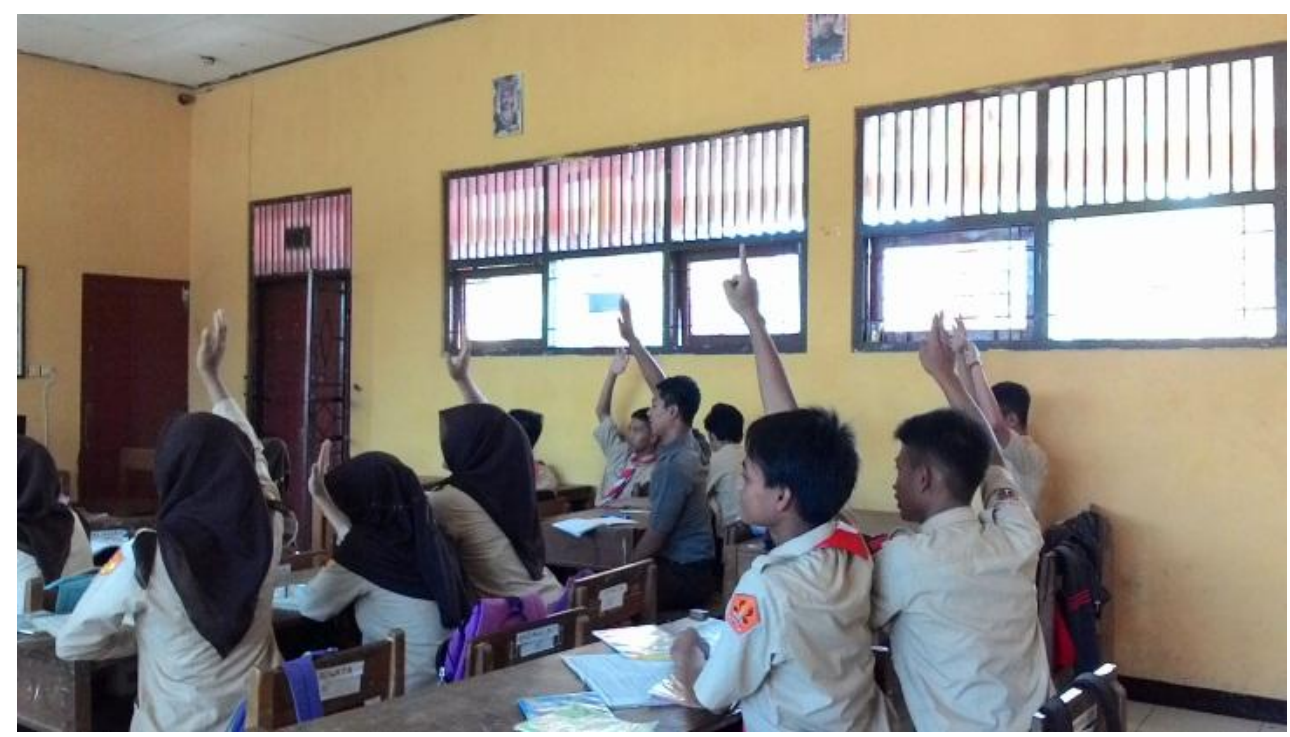

Gambar. 7 Sesi Tanya Jawab Siklus 2

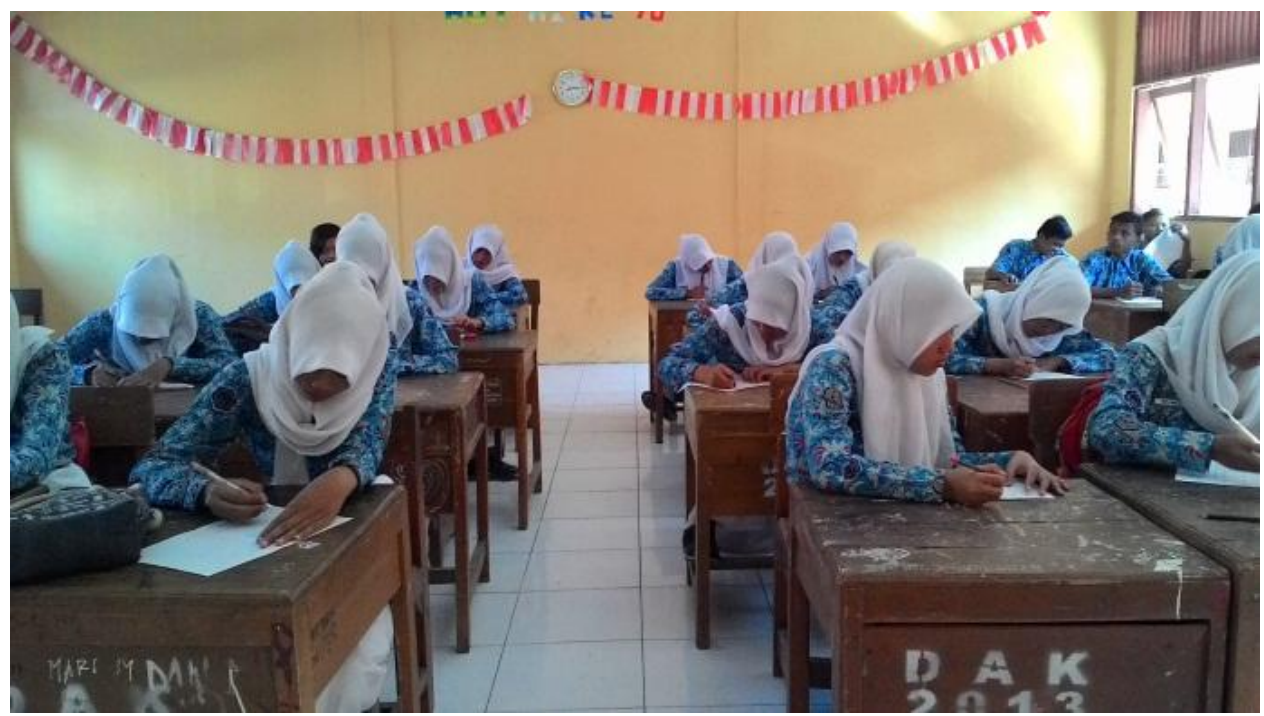

Gambar. 8 Evaluasi dari siklus 2

Motivasi belajar para siswa yang tinggi pada siklus 2 juga dapat dilihat dari gambar-gambar di atas, dimana para siswa berperan aktif dalam pembelajaran. Mereka bukan lagi sebagai obyek pembelajaran tetapi sebagai subyek. Mereka terlihat lebih serius mengikuti pembelajaran, lebih aktif bertanya dan menanggapi pemaparan makalah. Hal ini menunjukkan adanya peningkatan motivasi belajar siswa dibandingkan pada siklus 1 .

Berdasarkan data check list motivasi pada kegiatan belajar mengajar siklus 2, diperoleh data sebagai berikut: 
Tabel 5 Distribusi Frekuensi Motivasi Belajar Siswa Siklus 2 Kelas XI IPA SMA Negeri 1 Karangrayung

\begin{tabular}{|l|c|c|c|}
\hline Kategori & Nilai & Frekuensi & Persentase \\
\hline Sangat Baik & $91-100$ & 2 & $6,1 \%$ \\
\hline Baik & $81-90$ & 16 & $48,5 \%$ \\
\hline Cukup & $71-80$ & 12 & $36,4 \%$ \\
\hline Kurang & $0-70$ & 3 & $9,0 \%$ \\
\hline Jumlah & & 33 & $100 \%$ \\
\hline
\end{tabular}

Hasil dari check list motivasi belajar siswa dalam mengikuti pembelajaran sistem transportasi sebagaimana tabel 5 di atas menunjukkan bahwa ada 9,0\% siswa mempunyai motivasi kurang, sedangkan yang mempunyai termotivasi ada 91,0\%. Persentase motivasi belajar siswa yang meningkat akan menyebabkan hasil belajar siswa kelas XI IPA 1 pada siklus 1 juga mengalami peningkatan seperti pada data hasil evaluasi belajar siswa pada tabel berikut ini:

Tabel 6 Distribusi Nilai Hasil Belajar Siswa Siklus 2 Kelas XI IPA 1 SMA Negeri 1 Karangrayung

\begin{tabular}{|l|c|c|c|}
\hline Kategori & Nilai & Frekuensi & Persentase \\
\hline Sangat Baik & $91-100$ & 4 & $12,1 \%$ \\
\hline Baik & $81-90$ & 23 & $69.7 \%$ \\
\hline Cukup & $78-80$ & 2 & $6,1 \%$ \\
\hline Kurang & $0-78$ & 4 & $12,1 \%$ \\
\hline Jumlah & & 33 & $100 \%$ \\
\hline
\end{tabular}

Hasil belajar siswa pada materi sistem transportasi terlihat, bahwa $87,9 \%$ dari jumlah siswa di kelas XI IPA 1 yang telah tuntas belajar. Persentase sebesar itu tersebar pada 3 kategori yaitu cukup, baik, dan sangat baik. Untuk kategori cukup sebesar 6,1\%, baik sebesar 69,7\%, dan sangat baik sebesar 12,1\%. Sedangkan $12,1 \%$ dari jumlah siswa seluruhnya masih kurang nilainya.

Kriteria keberhasilan yang diharapkan dari penelitian ini sebesar $85 \%$, sedangkan menurut data pada siklus 2 menunjukkan bahwa ketuntasan belajar 
telah mencapai $87,9 \%$, hal ini menunjukkan bahwa penerapan model $S T A D$ dalam pembelajaran materi sistem transportasi telah berhasil.

\section{Pembahasan}

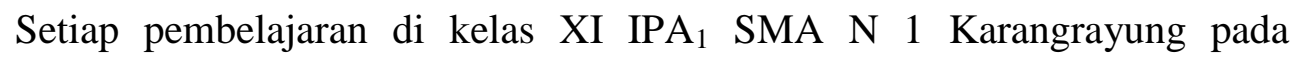
semester ganjil tahun 2015/2016 guru mengawali dengan apersepsi yang dilanjutkan dengan penyampaian materi sistem transportasi dengan metode ceramah. Untuk meningkatkan aktivitas dan pemahaman siswa guru telah berusaha melakukan tanya jawab akan tetapi tidak semua siswa mau aktif menjawab ataupun mengajukan pertanyaan kepada guru. Gambaran kegiatan belajar tersebut menunjukkan para siswa kurang termotivasi dalam mengikuti pelajaran tersebut.

Materi sistem transportasi merupakan materi yang saling terhubung antara tahap yang satu dengan tahap berikutnya. Materi pembelajaran merupakan proses yang melibatkan banyak kejadian oleh karena itu pemahaman untuk materi sistem transportasi juga tidak mudah walaupun guru sudah berusaha menyampaikan materi secara sederhana.

Berdasarkan temuan-temuan itu Peneliti merencanakan penelitian tindakan kelas bagi para siswa di kelas XI IPA 1 SMA N 1 Karangrayung semester ganjil tahun 2015/2016. Penelitian dilakukan dalam 2 siklus dengan menggunakan model STAD (Student Team Achievement divisions), pada siklus 1 mengambil materi sistem transportasi dengan indikator menjelaskan fungsi darah, jantung, dan pembuluh darah sedangkan pada siklus 2 mengambil materi sistem transportasi dengan indikator dasar-dasar transfusi darah.

Berdasarkan data-data dari hasil penelitian pada siklus 1 dan 2, maka data dari kedua siklus itu dapat dilihat pada tabel berikut ini: 
Tabel 9 Rekapitulasi Distribusi Frekuensi Motivasi Siswa Kelas XI IPA 1

\begin{tabular}{|l|l|l|l|l|}
\hline Kategori & Interval & Pra siklus & Siklus 1 & Siklus 2 \\
\hline Sangat Baik & $91-100$ & $1(3 \%)$ & $1(3 \%)$ & $2(6,1 \%)$ \\
\hline Baik & $81-90$ & $6(18,2 \%)$ & $11(33,3 \%)$ & $16(48,5 \%)$ \\
\hline Cukup & $71-80$ & $15(45,5 \%)$ & $15(45,5 \%)$ & $12(36,4 \%)$ \\
\hline Kurang & $0-70$ & $11(33,3 \%)$ & $6(18,2 \%)$ & $3(9 \%)$ \\
\hline Jumlah & & $33(100 \%)$ & $33(100 \%)$ & $33(100 \%)$ \\
\hline
\end{tabular}

Data dari tabel 9 di atas terlihat adanya kenaikan motivasi belajar siswa. Pada pra siklus motivasi belajar siswa hanya 66,7\%, setelah pembelajaran menerapkan model STAD pada siklus 1, motivasi siswa naik menjadi $81,8 \%$. Kenaikan motivasi siswa yang besar sekali yaitu sebesar 15,1\%. Kenaikan motivasi sebesar itu belum memenuhi indikator keberhasilan penelitian karena motivasi siswa yang diharapkan setelah pembelajaran menggunakan model STAD adalah $85 \%$. Oleh karena itu dilanjutkan dengan siklus 2, dimana nampak adanya kenaikan motivasi belajar siswa dibandingkan siklus 1 . Kenaikan persentase motivasi siswa pada siklus 2 sebesar 9,2\% dari siklus 1 atau sebesar 24,3\% dari pra siklus.

Berdasarkan analisis data motivasi belajar siswa kelas XI IPA1 di atas terlihat bahwa model pembelajaran STAD mampu meningkatkan motivasi belajar pada pembelajaran sistem transportasi bagi siswa kelas XI IPA1 SMA N 1 Karangrayung pada semester ganjil tahun ajaran 2015/2016.

Pentingnya peranan motivasi dalam proses pembelajaran adalah perlu dipahami guru agar dapat melakukan kegiatan atau bantuan kepada siswa dan peningkatan motivasi dengan cara menggunakan model pembelajaran yang menarik, tidak monoton serta tidak membosankan (Prof.Dr. Nana Syaodih Sukmadinata, 2005 : 61), yang dilakukan peneliti yaitu dengan menggunakan model pembelajaran $S T A D$, ternyata dapat meningkatkan motivasi belajar siswa. Sedangkan menurut Sardiman (2007:83) motivasi berfungsi sebagai penggerak untuk memperoleh prestasi belajar, dalam hal ini penggunaan model STAD pada pembelajaran sistem transportasi mampu menumbuhkan motivasi belajar siswa yang tinggi yang akan berdampak pada hasil belajar yang tinggi juga. 
Tabel 10 Rekapitulasi Distribusi Nilai Hasil Belajar Siswa Kelas XI IPA

\begin{tabular}{|l|l|l|l|l|}
\hline Kategori & Interval & Pra siklus & Siklus 1 & Siklus 2 \\
\hline Sangat Baik & $91-100$ & $1(3 \%)$ & $3(9,1 \%)$ & $4(12,1 \%)$ \\
\hline Baik & $81-90$ & $10(30,3 \%)$ & $17(51,3 \%)$ & $23(69,7 \%)$ \\
\hline Cukup & $78-80$ & $11(33,3 \%)$ & $7(21,2 \%)$ & $2(6,1 \%)$ \\
\hline Kurang & $0-78$ & $11(33,3 \%)$ & $6(18,2 \%)$ & $4(12,1 \%)$ \\
\hline Jumlah & & $33(100 \%)$ & $33(100 \%)$ & $33(100 \%)$ \\
\hline
\end{tabular}

Rekapitulasi distribusi nilai hasil belajar siswa kelas XI IPA1 SMAN 1 Karangrayung pada materi sistem transportasi terlihat bahwa penerapan model STAD dalam pembelajaran menunjukkan peningkatan hasil belajar siswa. Pada kondisi awal sebelum siklus penelitian, siswa yang mendapatkan nilai tuntas (diatas KKM 78) sebanyak 66,6\%. Pada siklus 1 setelah digunakan model STAD dalam pembelajaran, siswa yang tuntas belajar (nilai $\geq$ KKM 78) sebanyak 81,8\%. Hal ini menunjukkan adanya peningkatan hasil belajar siswa yaitu sebesar 15,2\%. Peningkatan hasil belajar siswa sebesar itu juga menandakan bahwa model STAD sangat efektif digunakan dalam pembelajaran sistem transportasi.

Walaupun sudah terdapat peningkatan yang signifikan yaitu sebesar 15,2\% akan tetapi nilai hasil belajar siswa yang tuntas belum memenuhi indikator kinerja yaitu $85 \%$ sedangkan pencapaian pada siklus 1 ini baru $81,8 \%$. Oleh karena itu penelitian dilanjutkan siklus 2 dengan lebih memaksimalkan peran model STAD dalam pembelajaran. Pemanfaatan STAD dalam pembelajaran sistem transportasi di siklus 2 ini dilengkapi dengan pemanfaatan media power point untuk membantu para siswa berpresentasi. Hasil belajar para siswa yang didapatkan dari evaluasi di akhir siklus 2 ini menunjukkan adanya peningkatan nilai sebesar $6,1 \%$ dari siklus 1 atau siswa yang mendapatkan nilai tuntas sebesar 87,9\%. Pencapaian hasil belajar siswa kelas XI IPA1 SMAN 1 Karangrayung di siklus 2 ini sudah baik yaitu 87,9\% sedangkan indikator kinerja yang diharapkan $85 \%$, oleh karena itu hasil dari siklus 2 ini sudah memenuhi indikator kinerja penelitian.

Menurut Dimyati dan Mujiono (2009:3), hasil belajar merupakan puncak dari proses belajar. Sesuai dengan pendapat Dimyati dan Mujiono (2009:3), hasil belajar yang tinggi pada siklus 2 sebagai hasil dari tingginya motivasi belajar 
siswa kelas XI IPA1 selama proses pembelajaran. Selain itu hasil belajar yang tinggi pada siklus 2 juga disebabkan adanya perubahan pada semua siswa kelas XI IPA1 SMA N 1 Karangrayung selama proses pembelajaran sistem transportasi (Wahidmurni, dkk; 2010:18).

Berikut ini peneliti tampilkan Diagram Motivasi Belajar, Hasil Belajar sebelum dan setelah model pembelajaran STAD.

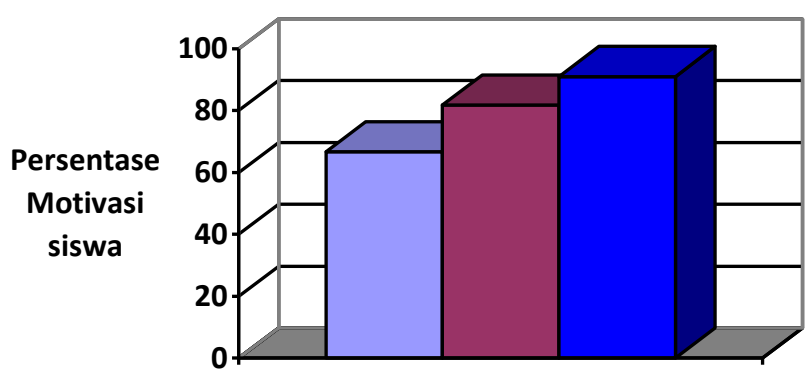

$\square$ Pra Siklus $\square$ Siklus $1 \square$ Siklus 2

Gambar 9. Grafik Diagram Motivasi Belajar

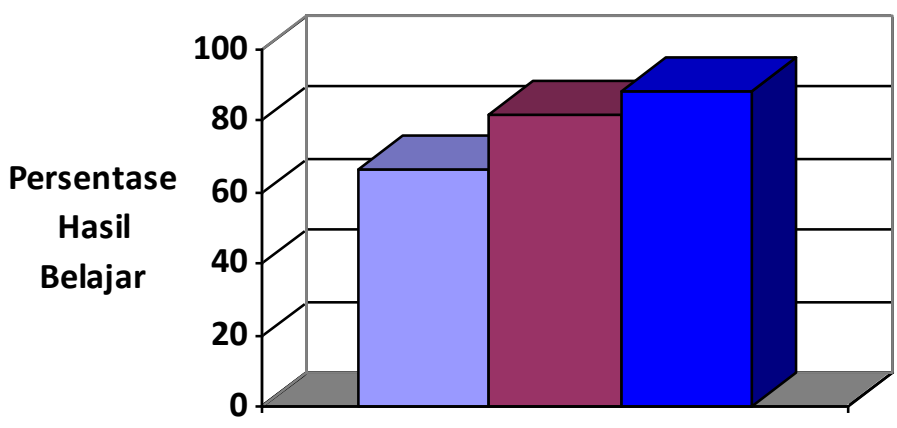

$\square$ Pra Siklus $\square$ Siklus 1 a Siklus 2

Gambar 10. Grafik Diagram Hasil Belajar

Peningkatan motivasi dan hasil belajar siswa kelas XI IPA1 SMAN 1 Karangrayung dengan menggunakan model pembelajaran STAD dalam materi sistem transportasi dipertegas oleh grafik diagram motivasi dan hasil belajar siswa di atas. Jelas sekali terlihat pada grafik adanya peningkatan yang sangat signifikan dari pra siklus sampai siklus 2, hal ini menguatkan bahwa model STAD sangat 
efektif untuk meningkatkan motivasi dan hasil belajar siswa pada penelitian ini. Motivasi belajar siswa yang tinggi akan meningkatkan pula hasil belajar terutama pada materi sistem transportasi bagi siswa kelas XI IPA1 di SMA N 1 Karangrayung tahun ajaran 2015/2016.

\section{KESIMPULAN}

Kesimpulan hasil penelitian ini, bahwa proses pembelajaran biologi dengan menggunakan model STAD (Student Team Achievement Divisions) dapat meningkatkan:1) motivasi siswa dalam materi sistem transportasi bagi siswa kelas XI IPA1 SMA Negeri 1 Karangrayung semester ganjil tahun 2015/2016, 2) hasil belajar siswa dalam materi sistem transportasi bagi siswa kelas XI IPA1 SMA Negeri 1 Karangrayung semester ganjil tahun 2015/2016. 


\section{DAFTAR PUSTAKA}

A.M., Sardiman. 2007. Interaksi dan Motivasi Belajar Mengajar. Jakarta: PT Raja Grafindo Persada.

Dimyati dan Mudjiono. 2009. Belajar dan Pembelajaran. Jakarta : PT. Rineka Cipta.

E.Mulyasa. 2003. Kurikulum Berbasis Kompetensi ,Konsep, Karakteristik dan Implementasi. Bandung: FPTK - IKIP Bandung

Slameto. 2003. Belajar dan Faktor-Faktor yang Mempengaruhinya. Jakarta: Rineka Cipta

Sukmadinata, Nana Syaodih. 2005. Landasan Prikologi Proses Pendidikan. Bandung : PT. Remaja Rosda Karya Hal. 61.

Suparman. 2010. Gaya Mengajar yang Menyenangkan Siswa. Yogyakarta:Penerbit Pinus.

Susilana, Rudi dan Cepi Riyana. 2007. Media Pembelajaran. Bandung: CV Wacana Prima.

Wahab.A.A.2009. Metode dan Model-model Pembelajaran. Bandung: Alfabeta.

Wahidmurni,dkk. 2010. Evaluasi Pembelajaran : Kompeteni dan Praktik. Yogyakarta : Nuha Letera.

(HTML). M.S. Sutikno. 2007. Peran Guru dalam Membangkitkan Motivasi Belajar Siswa. Blog.binadarma.ac.id. diunduh tanggal 10 Juli 2015. 